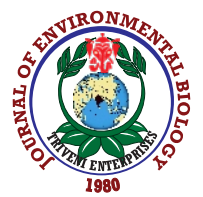

\title{
Effects of mycorrhizal inoculation on growth and some quality parameters of Matthiola incana (L.) cultivation under salt stress
}

\section{H. Akat ${ }^{*}$}

Ortaca Vocational School, Department of Parks and Horticulture, Muğla Sıtkı Koçman University, 48600, Ortaca-Mugla, Turkey

*Corresponding Author Email : hulya_akat@hotmail.com

\section{Abstract}

Aim: This research was carried out to investigate the effect of mycorrhizal inoculation on growth and some quality parameters of Matthiola incana cultivation under salt stress condition.

Methodology : The experiment was carried out in a greenhouse in Mugla-Turkey between 2016 and 2017. There were three replications with two factorial randomized plot design. Plant were given two treatments endomycorrhizal inoculation of Glomus intraradices in the root zone of plants without $\mathrm{NaCl}$ and $100 \mathrm{mM} \mathrm{NaCl}$. The number of shoot, shoot length, shoot thickness, root length, wet and dry weights of root, leaf number on the pedicel, length and thickness of pedicel, length of spike, wet and dry weights of pedicel were estimated. The percentage of mycorrhizal infection, total $\mathrm{N}, \mathrm{P}, \mathrm{K}, \mathrm{Ca}, \mathrm{Na}, \mathrm{Mg}, \mathrm{Fe}, \mathrm{Cu}$, $\mathrm{Zn}$ and $\mathrm{Mn}$ contents in the roots were also determined.

Results : In all parameters, salt application had greatly diminished the performance of plants. However, mycorrhizal inoculation after salt application had effected the shoot and root growth as well as quality parameters of flower.

Interpretation: The results showed that mycorrhizal application to $M$. incana positively effected the plant growth and some quality parameters by increasing tolerance towards salt stress.

Keywords: Floriculture, Glomus intraradices, Matthiola incana, Mycorrhizal inoculation, Salt stress

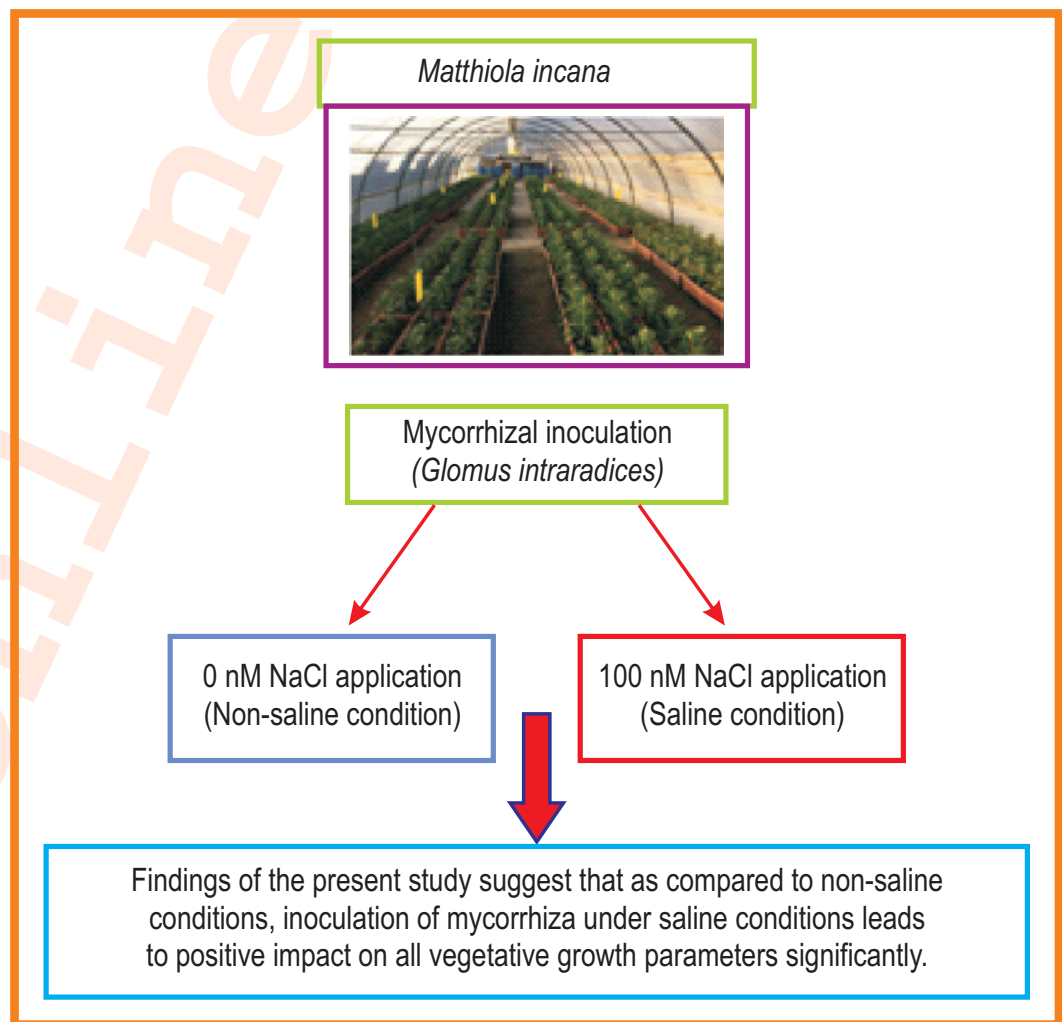

How to cite : Akat, H.: Effects of mycorrhizal inoculation on growth and some quality parameters of Matthiola incana (L.) cultivation under salt stress. J. Environ. Biol., 41, 375-381 (2020). 


\section{Introduction}

Parallel to increase in global temperature, the increase in soil salinity around the world is restricting the use of such areas for cultivation. This stresses the fact to look for an alternative application to overcome soil degradation effects arising from salinity (Vibhuti et al., 2015; Shahi et al., 2015; Awasthi et al., 2016). One way to overcome such problem is increased tolerance to salinity stress. Application of mycorrhizal fungus to the growth medium or roots, commonly known as biological fertiliser, leads to increased plant growth in degraded soils (Al Karaki, 2000; Cekic and Yilmaz, 2011). Mycorrhiza inoculation is reported to increase the uptake of water and nutrients, leading to growth enhancement, increased tolerance against stress factors and increased the productivity (Kaya et al., 2009; Miao Xie et al., 2017). Several studies carried out in this direction during the last decade have reported that mycorrhiza can overcome the negative effects of salinity as a bioregulator under abiotic stress factor (Rabie and Almadini, 2005; Kumbar et al., 2017). Salt stress increases the problem of nutrient limitation but arbuscular mycorrhizal fungus increases the total root area with length of external mycelium enhancing the reabsorbation capacity and provides higher accumulation of soluble sugars in plant roots under saline conditions (Jakobsen et al., 1992; Feng et al., 2002). Glomus intra radices an arbuscular mycorrhizal fungus (AMF) is a type of mycorrhiza widely preferred at industrial level, because of its adaptation to several soil types, showing colonisation with numerous hosts, early prorogation and preserving living conditions for longer periods. This research was carried out to investigate the effect of mycorrhizal inoculation on growth and some quality parameters of $M$. incana under salt stress condition.

\section{Materials and Methods}

Matthiola incana (L.) is an ornamental plant that belongs to Brassicaceae family. This species has different varieties which produce single and double flowers. The flowers have pleasant smell and are short-living perennial species widely distributed in the Mediterranean region (Shanan, 2015). The study was undertaken during the year 2016-2017 in a greenhouse following two factorial random plot design in triplicate, using 9 plants per replica. M. incana 'Iron Apricot' cultivar was selected as plant material. In order to get a product without any deformation in quality on economical terms, the salt and mycorrhiza were applied together as two factorial design, in order to see if better growth performance could be obtained. Treatment was given as non saline(S0) and $100 \mathrm{mM} \mathrm{NaCl}$ (S1) added with irrigation water. Glomygel (Glomus intraradices, Mycovitro) was used as source of mycorrhiza. Mycorrhizal application included AMF0 concentration as control without mycorrhiza and AMF1concentration as $100 \mathrm{~g} \mathrm{da}^{-1}$ on the lines recommended for industrial scale. The soil was sterilized at $100^{\circ} \mathrm{C}$ for $180 \mathrm{~min}$. AMF inoculum was added to pot soil with irrigation water at planting time. The plants were sown in 26 I pots and salt treatment was started on 22.11.2016 followed by once a week application.15 days after sowing, root zone of plants were inoculated with mycorrhiza after dissolving in water with the suggested concentration (Table 1).

Once a week Hoagland solution ( $\mathrm{pH}$ 5.5-6.5) was supplied as nutrients to plants (Brohi et al., 1994). Salinity level was determined as per to Richards (1954), pH with Beckman pH meter, organic matter was calculated following the method of Reuterberg ve Kremkus (Black, 1965), total nitrogen by Bremner and Shaw's modified macro Kjeldal method (Bremner,1965) and sodium according to Kacar (1972)(Table 2).

In this research after salt and mycorrhiza application, number of leaves on shoot, shoot length and thickness, root length, wet and dry weights of root, leaf number on the pedicel, length and thickness of pedicel, length of spike, wet and dry weights of pedicel was recorded. In roots, mycorrhizal infection percentage was determined without staining using "Grid Line Intersection" method (McGonigle et al., 1990). Macro and micro elements were analysed. Nitrogen was determined by Kjeldahl method, Phosphorus by Vanadomolybdo phosphoric yellow

Table 1: Production schedule of the study

\begin{tabular}{ll}
\hline Applications & Date of application \\
\hline Seed sowing & 09.09 .2016 \\
Transplantation & 13.10 .2016 \\
Planting & 15.11 .2016 \\
First saltapplication & 22.11 .2016 \\
Mycorrhiza application & 30.11 .2017 \\
Firstharvest & 16.02 .2017 \\
End of the experiment & 01.04 .2017 \\
\hline
\end{tabular}

Table 2: Physical and chemical characteristics of soil used

\begin{tabular}{lllllll}
\hline Texture & $\mathrm{pH}(1: 2.5)$ & Salt $(\%)$ & $\mathrm{CaCO}_{3}(\%)$ & Organic matter $(\%)$ & Total N $(\%)$ & $\mathrm{Na}(\mathrm{ppm})$ \\
\hline Sandy-loam & 7.88 & 0.02 & 11.40 & 4.00 & 0.19 & 86.00 \\
\hline
\end{tabular}


colour method with the help of Eppendorf Calorimeter; potassium, sodium, and calcium were determined with Flame Photometer; whereas magnesium, iron, copper, zinc and manganese by Atomic Absorption Spectrophotometer ( Kacar and Inal, 2008). The results obtained were statistically analyzed SPSS (11.0) statistical package programme.

\section{Results and Discussion}

The results related to mycorrhizal inoculation in the roots are presented in Table 3. Mycorrhizal colonisation was observed under both saline as well as non-saline conditions without mycorrhizal application, depicting that soils possess mycorrhizal colonies under natural conditions. Mycorrhizal colonization in the roots under non-saline conditions was $65.67 \%$ whereas under saline conditions it was $36 \%$. Mycorrhiza colonization of Citrus karna and Poncirus trifoliata x Citrus sinensis under salt stress decreased from $66.8 \%$ and $62.4 \%$ to $31.3 \%$ and $39.7 \%$ as compared to non-saline salt stress (Murkute et al., 2006). These results corroborates with our findings. In our study, the colonisation ratio in the roots decreased by $65.67 \%$ and $36 \%$ after mycorrhizal application under non-saline and saline conditions.
The role of mycorrhizal application on the vegetative growth of plant is presented in Table 3. Salt application significantly decreased the number of shoot and shoot length whereas other parameters showed negative relation. Salt stress decreased the length of root, shoot and stem, leaf number, dry and fresh weight in addition to leaf area (Koksal et al., 2014). Application of salt to Matthiola incana decreased the plant growth parameters by approximately 8 to $20 \%$. As compared to many cut flowers, the decrease due to negative effects of salt can be accepted on the trade scale in the case of $M$. incana. Heuer and Ravina (2004) and Grieve et al. (2006) in this study reported that although increased levels of salt can negatively effect the growth and development of $M$. incana, but this effect does not change the market productivity. These findings corroborates with our results.

On the other hand, mycorrhizal application positively affected all growh parameters at $p<0.01$. AMF application generally increases quality of ornamental plants (Puschel et al., 2014). According to Sohn et al. (2003), AMF inoculation in Chrysanthemum morifolium leads to increase in plant height, leaf area, dry and wet weight of stem, shoot, and root. Meir et al. (2010) also reported similar results and data of this study is also in confirmation with the above studies.

Table 3: Mycorrhizal inoculation and the effect of mycorrhizal application on plant growth

\begin{tabular}{|c|c|c|c|c|c|}
\hline \multirow{3}{*}{$\begin{array}{l}\text { Treatments } \\
\mathrm{S} \\
\mathrm{S} 1\end{array}$} & & \multicolumn{2}{|l|}{ Mycorrhizal inoculation (\%) } & \multicolumn{2}{|c|}{ Leaf number of shoot (per plant ${ }^{-1}$ ) } \\
\hline & & $36.94^{\mathrm{a}}$ & & & \\
\hline & & $18.67^{b}$ & & & \\
\hline $\operatorname{LSD}_{0.05}$ & & $3.72^{*}$ & & & \\
\hline AMFO & & $4.77^{\mathrm{b}}$ & & & \\
\hline AMF1 & & $50.84^{\mathrm{a}}$ & & & \\
\hline $\operatorname{LSD}_{0.05}$ & & $3.72^{\star *}$ & & & \\
\hline SO*AMF0 & & $8.20^{\circ}$ & & & \\
\hline S0*AMF1 & & $65.67^{\mathrm{a}}$ & & & \\
\hline$S 1^{*} \mathrm{AMFO}$ & & $1.33^{d}$ & & & \\
\hline S1*AMF1 & & $36.00^{\mathrm{b}}$ & & & \\
\hline $\operatorname{LSD}_{0.05}$ & & $5.47^{* *}$ & $\mathrm{n}$ & & \\
\hline Treatments & Shoot length $(\mathrm{cm})$ & Shoot thickness (mm) & Root length (cm) & Root fresh weight (g) & Root dry weight (g) \\
\hline$S$ & $27.15^{\mathrm{a}}$ & $4.53^{\mathrm{a}}$ & $19.83^{\mathrm{a}}$ & $11.04^{\mathrm{a}}$ & $1.74^{\mathrm{a}}$ \\
\hline S1 & $23.57^{b}$ & $4.19^{b}$ & $17.17^{b}$ & $9.32^{b}$ & $1.40^{\mathrm{b}}$ \\
\hline $\operatorname{LSD}_{0.05}$ & $3.12^{*}$ & $0.22^{* *}$ & $1.71^{* *}$ & $0.86^{* *}$ & $0.10^{\star *}$ \\
\hline AMF0 & $22.33^{\mathrm{b}}$ & $4.06^{b}$ & $15.94^{b}$ & $9.09^{b}$ & $1.36^{\mathrm{b}}$ \\
\hline AMF1 & $28.39^{\mathrm{a}}$ & $4.67^{\mathrm{a}}$ & $21.05^{\mathrm{a}}$ & $11.28^{\mathrm{a}}$ & $1.79^{\mathrm{a}}$ \\
\hline $\operatorname{LSD}_{0.05}$ & $3.12^{* *}$ & $0.22^{* \star}$ & $1.71^{* *}$ & $0.86^{* \star}$ & $0.10^{* *}$ \\
\hline SO*AMFO & 24.17 & 4.26 & 17.50 & 10.02 & 1.53 \\
\hline S0*AMF1 & 30.14 & 4.80 & 22.16 & 12.07 & 1.95 \\
\hline S1*AMF0 & 20.50 & 3.85 & 14.39 & 8.16 & 1.19 \\
\hline S1*AMF1 & 26.64 & 4.53 & 19.94 & 10.49 & 1.62 \\
\hline $\mathrm{LSD}_{0.05}$ & $\mathrm{~ns}$ & ns & ns & ns & ns \\
\hline
\end{tabular}

S0: Non saline; S1: $100 \mathrm{mM} \mathrm{NaCl}$ application; AMF0: Without mycorrhiza (Control); AMF1:Application of $100 \mathrm{~g}$ da ${ }^{-1}$ Glomus intraradices; ns: nonsignificant; Within each column, values followed by same letters are not significantly different as per LSD test; ** Significant at $p<0.01$; ${ }^{*}$ Significant at $p<0.05$ level 
Mycorrhiza is known to increase the nutrient uptake and plant growth in many studies (Shokri and Maadi, 2009; Asrar and Elhindi, 2011). It is also clear that the advancement of nutrient uptake and plant growth increase salt resistance due to improvement of root and soil conditions. In this context, our results are consistent with the previous studies.

In case of salt-mycorrhiza interactions, mycorrhizal application under saline condition ( $\left.1{ }^{*} \mathrm{AMF} 1\right)$, as compared to control treatment under saline condition ( $\left.11^{*} \mathrm{AMF} 0\right)$, revealed that there was an increase in the leaf number of shoot by $18.69 \%$, shoot length by $29.95 \%$, shoot thickness by $17.66 \%$, root length by $38.56 \%$, root fresh weight $28.55 \%$ and root dry weight by $36.13 \%$. As compared to control (S0*AMF0), mycorrhizal application under non-saline condition (SO*AMF1) led to increase in leaf number of shoot (13.73\%), shoot length $(24.70 \%)$, shoot thickness $(12.67 \%)$, root length $(26.62 \%)$, root fresh weight $(20.45 \%)$ and root dry weight $(27.45 \%)$. As compared to nonsaline conditions, application of mycorrhiza under saline conditions led to positive impact on all vegetative growth parameters. Therefore, a decrease in the growth values due to salt application, with mycorrhizal application as compared to the mycorrhizal application under non-saline conditions makes it more important. According to the control (S0*AMF0), mycorrhiza application under saline condition $\left(S 1^{*} \mathrm{AMF} 1\right)$ had lead to increase in leaf number (5.88\%), shoot length (10.21\%), shoot thickness $(6.33 \%)$, root length (13.94\%), root dry weight (4.69\%), root weight $(5.88 \%)$ and increase the rates of plant growth were also observed in mycorrhiza condition despite salt application. A decrease in plant growth due to salinity conditions was reversed by mycorrhizal application with positive effects in different parameters in different ratios. Some studies have shown that AMF inoculation develops salt resistance through advanced osmoregulation (Feng et al., 2002). Sonmez et al. (2013) have reported that a decrease in plant height and fresh weight due to salt application, mycorrhizal application under salt conditions increased plant dry and fresh weight to a great extent. Geren et al., (2011) reported that with Lathyrus ochrus, increase in salt concentration, root dry and fresh weight are negatively affected whereas mycorrhizal application produced a positive impact on the plant physiological behaviour. In addition, several studies have reported that mycorrhizal application positively affect plant growth due to increased nutrient uptake (Shokri and Maadi, 2009).

Table 4 presents data on the parameters related to flower quality. The effect of salt and mycorrhiza separately on leaf number of pedicel, pedicel length and thickness, spike length, dry and fresh weight of pedicel resulted in a difference significant at $p<0.01$. Under the following treatments, interaction of salt and mycorrhiza, mycorrhiza application under salt stress (S1*AMF1), in comparison to the situation without mycorrhiza under salt stress (S1*AMF0) increase the number of leaf pedicel $(21.09 \%)$, pedicel length (15.03\%), pedicel thickness (31.36\%), spike length (26.53\%), fresh weight of pedicel $(14.46 \%)$ and dry weight of pedicel (47.07\%). Similarly, in the case of mycorrhiza application without salt (S0*AMF1), when compared to the control (S0*AMF), significant increase in number of leaf pedicel $(12.74 \%)$, pedicel length $(17.79 \%)$, pedicel thickness $(30.92 \%)$, spike length $(26.46 \%)$, fresh weight of pedicel $(15.41 \%)$ and dry weight of pedicel $(47.98 \%)$ was noted.

Application of mycorrhiza under salt stress condition, when compared with control, showed increase in leaf number on the pedicel by $4.02 \%$, pedicel length by $7.98 \%$, pedicel thickness by $9.50 \%$, spike length by $8.82 \%$, fresh weight of pedicel by

Table 4 : Efect of mycorrhizal application on flower quality

\begin{tabular}{|c|c|c|c|c|c|c|}
\hline Treatments & 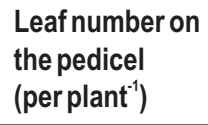 & $\begin{array}{l}\text { Pedicel length } \\
\text { (cm) }\end{array}$ & $\begin{array}{l}\text { Pedicel } \\
\text { thickness } \\
(\mathrm{mm})\end{array}$ & $\begin{array}{l}\text { Spike length } \\
(\mathrm{cm})\end{array}$ & $\begin{array}{l}\text { Pedicel } \\
\text { fresh weight } \\
\text { (g) }\end{array}$ & $\begin{array}{l}\text { Pedicel } \\
\text { dry weight } \\
\text { (g) }\end{array}$ \\
\hline$S$ & $52.83^{\mathrm{a}}$ & $59.17^{\mathrm{a}}$ & $16.17^{\mathrm{a}}$ & $10.27^{\mathrm{a}}$ & $121.11^{\mathrm{a}}$ & $24.63^{a}$ \\
\hline S1 & $47.17^{b}$ & $54.83^{b}$ & $13.50^{b}$ & $8.83^{b}$ & $115.13^{b}$ & $21.33^{b}$ \\
\hline $\operatorname{LSD}_{0.05}$ & $1.88^{* *}$ & $2.18^{* *}$ & $1.49^{* *}$ & $0.57^{\star \star}$ & $4.60^{* *}$ & $2.42^{\star *}$ \\
\hline AMF0 & $46.17^{\mathrm{b}}$ & $52.67^{b}$ & $12.83^{b}$ & $8.43^{b}$ & $109.90^{b}$ & $18.56^{b}$ \\
\hline AMF1 & $53.83^{\mathrm{a}}$ & $61.33^{\mathrm{a}}$ & $16.83^{\mathrm{a}}$ & $10.67^{\mathrm{a}}$ & $126.33^{\mathrm{a}}$ & $27.40^{\mathrm{a}}$ \\
\hline $\mathrm{LSD}_{0.05}$ & $1.88^{* *}$ & $2.18^{* *}$ & $1.49^{* *}$ & $0.57^{* *}$ & $4.60^{* *}$ & $2.42^{* *}$ \\
\hline SO*AMF0 & 49.67 & 54.33 & 14.00 & 9.07 & 112.44 & 19.86 \\
\hline SO*AMF1 & 56.00 & 64.00 & 18.33 & 11.47 & 129.77 & 29.39 \\
\hline S1*AMF0 & 42.67 & 51.00 & 11.67 & 7.80 & 107.36 & 17.27 \\
\hline S1*AMF1 & 51.67 & 58.67 & 15.33 & 9.87 & 122.89 & 25.40 \\
\hline $\mathrm{LSD}_{0.05}$ & ns & ns & ns & ns & ns & ns \\
\hline
\end{tabular}

S0: Non saline; S1: $100 \mathrm{mM} \mathrm{NaCl}$ application; AMF0: Without mycorrhiza (Control); AMF1:Application of $100 \mathrm{~g}$ da ${ }^{-1}$ Glomus intraradices; ns: nonsignificant; Within each column, values followed by same letters are not significantly different as per LSD test; ** Significant at $p<0.01$; * Significant at $p<0.05$ level. 
$9.29 \%$ and dry weight of pedicel by $27.89 \%$, respectively. In parallel with plant growth, quality of flowers was also a effected in the same condition. All the growth parameters decreased under salt treatment but with mycorrhizal inoculation all the studied growth parameters increased. The results obtained in $0.674 \%$ salt condition by Akat and Ozzambak (2013) showed that Limonium sinuatum 'Compindi White' flower peduncle thickness showed $10.61 \%$ loss and L. sinuatum 'Compindi Deep Blue' showed $19.64 \%$ loss. Similarly, significant negative effects of salinity on flower quality and growth has been reported (Carter and Grieve, 2006; Akat and Ozzambak, 2014;Akat and AkatSaracoglu, 2017). Salt application Gerbera jamesonii (Akat, 2008). Hyacinthus orientalis (Koksal et al., 2014) produced negative effect on pedicel length and thickness. Bessemer and Koide (1999) reported that mycorrhiza produce a positive effect on the flowering of Narcissus papyroceus and Antirrhinum majus by increasing the number of flowers and their vase life. According to Sohn et al. (2003), AMF inoculation in Chrysynthemum sp. lead to important difference in the pedicel thickness and length as well as fresh weight of pedicel, thus effecting the above growth parameters and flowering time in a positive way. In the case of Eustoma grandiflorum, G. intrradices application increased the number of flowers and length of pedicel (Meir et al., 2010). It has also been helpful on the market level for cultivating Lisianthu ssp. and its use in other ornamental plants has been stressed with the fact that they may show similar potential. Similarly, mycorrhizal application in Tagates erecta produced positive effects on all parameters related to flower (Asrar and Elhindi, 2011). Moreover, application of AMF increased the number of flowers and their quality (Long et al., 2010; Deljou et al., 2014). The results obtained during present study clearly show that application of mycorrhiza under non-saline condition increased flower development and quality. Mycorrhizal involvement under salt application clearly shows that with regard to different parameters related to flower quality, negative impact is overrrun in different ratios. In floriculture, AMF application has shown positive effects on flower quality, flower growth and flowering time (Miao Xie et al., 2017).

The perusal of data showed that salt application had decreased nitrogen, calcium, zinc and manganese contents by $1 \%$; phosphorus potassium and magnesium level by $5 \%$, however, sodium level increased after salt application. Mycorrhizal application in roots had increased the levels of nitrogen, calcium, zinc and manganese at $1 \%$ level, and for potassium at $5 \%$ level (Table 5). The large hyphal system of AMF discovered more soil area and enhanced the absorption surface of roots, thus contributing towards an increase in the elemental

Table 5 : Effect of mycorrhizal application on the nutrient contents in roots

\begin{tabular}{lllllll}
\hline Treatments & $\mathbf{N}(\%)$ & $\mathbf{P}(\%)$ & $\mathrm{K}(\%)$ & $\mathrm{Ca}(\%)$ & $\mathrm{Mg}(\%)$ & $\mathrm{Na}(\%)$ \\
\hline $\mathrm{S}$ & $1.78^{\mathrm{a}}$ & $0.38^{\mathrm{a}}$ & $2.64^{\mathrm{a}}$ & $0.48^{\mathrm{a}}$ & $0.44^{\mathrm{a}}$ & $0.07^{\mathrm{b}}$ \\
$\mathrm{S} 1$ & $1.56^{\mathrm{b}}$ & $0.35^{\mathrm{b}}$ & $2.47^{\mathrm{b}}$ & $0.32^{\mathrm{b}}$ & $0.31^{\mathrm{b}}$ & $0.45^{\mathrm{a}}$ \\
LSD $_{0.05}$ & $0.045^{* *}$ & $0.021^{*}$ & $0.129^{*}$ & $0.038^{\star *}$ & $0.091^{*}$ & $0.021^{* *}$ \\
$\mathrm{AMF0}$ & $1.61^{\mathrm{b}}$ & 0.36 & $2.47^{\mathrm{b}}$ & $0.37^{\mathrm{b}}$ & 0.34 & 0.26 \\
AMF1 & $1.72^{\mathrm{a}}$ & 0.37 & $2.64^{\mathrm{a}}$ & $0.43^{\mathrm{a}}$ & 0.41 & 0.25 \\
LSD $_{0.05}$ & $0.045^{* *}$ & $\mathrm{~ns}$ & $0.129^{*}$ & $0.038^{* *}$ & $\mathrm{~ns}$ & $\mathrm{~ns}$ \\
S0AMF0 & 1.74 & 0.38 & 2.61 & 0.45 & 0.39 & 0.07 \\
S0*AMF1 & 1.82 & 0.39 & 2.67 & 0.51 & 0.49 & 0.07 \\
S1*AMF0 & 1.49 & 0.35 & 2.34 & 0.29 & 0.29 & 0.46 \\
S1 $1^{*}$ AMF1 & 1.63 & 0.36 & 2.61 & 0.35 & 0.34 & 0.44 \\
LSD $_{0.05}$ & $\mathrm{~ns}$ & $\mathrm{~ns}$ & $\mathrm{~ns}$ & $\mathrm{~ns}$ & $\mathrm{~ns}$ & $\mathrm{~ns}$ \\
\hline
\end{tabular}

\begin{tabular}{lllll}
\hline Treatments & $\mathrm{Fe}(\mathrm{ppm})$ & $\mathrm{Cu}(\mathrm{ppm})$ & $\mathrm{Zn}(\mathrm{ppm})$ & $\mathrm{Mn}(\mathrm{ppm})$ \\
\hline $\mathrm{S}$ & 377.20 & $16.42^{\mathrm{a}}$ & $38.28^{\mathrm{a}}$ & $40.27^{\mathrm{a}}$ \\
$\mathrm{S} 1$ & 378.63 & $13.10^{\mathrm{b}}$ & $31.52^{\mathrm{b}}$ & $34.20^{\mathrm{b}}$ \\
LSD $_{0.05}$ & $\mathrm{~ns}$ & $0.783^{* *}$ & $2.249^{* *}$ & $2.875^{* *}$ \\
$\mathrm{AMF0}$ & 325.42 & 14.40 & $32.50^{\mathrm{b}}$ & $34.87^{\mathrm{b}}$ \\
$\mathrm{AMF1}$ & 430.41 & 15.12 & $37.30^{\mathrm{a}}$ & $39.60^{\mathrm{a}}$ \\
LSD $_{0.05}$ & $\mathrm{~ns}$ & $\mathrm{~ns}$ & $2.249^{* *}$ & $2.875^{* *}$ \\
S0*AMF0 & 378.65 & 16.50 & 36.03 & 38.45 \\
S0AMF1 & 375.75 & 16.35 & 40.54 & 42.10 \\
S1*AMF0 & 272.20 & 12.30 & 28.98 & 31.30 \\
S1*AMF1 & 485.07 & 13.90 & 34.06 & 37.10 \\
LSD $_{0.05}^{*}$ & $\mathrm{~ns}$ & $\mathrm{~ns}$ & $\mathrm{~ns}$ & $\mathrm{~ns}$ \\
\hline
\end{tabular}

S0: Non saline; S1: $100 \mathrm{mM} \mathrm{NaCl}$ application; AMF0: Without mycorrhiza (Control); AMF1:Application of $100 \mathrm{~g}$ da ${ }^{-1}$ Glomus intraradices; ns: nonsignificant; Within each column, values followed by same letters are not significantly different as per LSD test; ** Significant at $p<0.01$; * Significant at $p<0.05$ level 
concentration in AMF plants (Ruiz-Lozano and Azcon, 2000). Similarly, Abd El Aziz et al. (2011) reported that with increase in salt concentration, uptake of nitrogen, phosphorus and potassium and content decreased in M. incana. Shanan (2015) reported that in $M$. incana, stress created due to salt application increased sodium and chloride ions as well as proline content. Plants under salt stress showed increase in the level of sodiumion followed by a decrease in the potassium ion (Turkan and Demiral, 2008). Under saline conditions $\mathrm{Na}^{+} / \mathrm{K}^{+}$ratio is abnormally high and makes enzymes more uneffective by inhibiting protein synthesis. This destroyed protein metabolism as compared to control can be explained by reduction in the nitrogen uptake. According to Soliman et al. (2012), decrease in the NPK and microelements is related to increase in the percentage of sodium and chloride. $\mathrm{Na}$ salts increase the $\mathrm{pH}$ of soil and uptake of $\mathrm{P}$ is limited. In addition, under stress conditions there is decrease in the mineral element contents as compared to the control is because, in order to reduce the solute potential in cystole the balance created by the synthesis of soluble components like glycine, betaine, proline, sorbitol, mannitol, pinitol, and saccharose gives answer against salt stress. As it is well known, mycorrhizal application increases the nutrient content in plants. According to Sieverding (1991) and Ortas (2012), mycorrhizal application supports our findings that refinement of root cells increases the uptake of most minerals, except phosphorus. There is no significant difference between salt and mycorrhiza interactions. Under salt conditions nonmycorrhizal application (S1*AMF0), in comparison to mycorrhizal application $\left(\mathrm{S} 1^{*} \mathrm{AMF} 1\right)$ increased all plant nutrients, except $\mathrm{Na}$ (Table 5).

M. incana 'Iron Apricot' variety tolerant to medium salt level was negatively affected under saline conditions in connection to all parameters related to plant growth and flower quality leading to economic loss. In view of this, negative effects imposed by salt application were slightly overcomed by mycorrhizal application by increasing tolerance to salt stress. In particular, the growth of $M$. incana was dense under green house as well as under open conditions with mycorrhizal application. The effects on growth and flower quality were on positive side, by increasing tolerance to salt stress it can add to the economy. This study has fully enlightened that mycorrhiza can be used as a positive strategy to increase tolerance to salt stress, which should be applied on other ornamental plants as well. Under non-saline conditions mycorrhizal application can increase the quality of flowers and plant growth, and at the same time can prove useful for the producers using fertilisers so as to bring down their monetary input.

\section{Acknowledgments}

Authors are thankful to the Director of Muğla Sıtkı Koçman University Ortaca Vocational School for permitting into use the greenhouse for conducting experiment.

\section{References}

Abd El Aziz, N.G., M.A. Mazher and H.M. Mahgoub: Influence of using organic fertilizer on vegetative growth, flowering and chemical constituents of Matthiola incana plant grown under saline water irrigation. World J. Agric. Sci., 7, 47-54 (2011).

Akat, H. and M.E. Ozzambak: The effects of $\mathrm{Ca}$ application on some stress parameters of Limonium sinuatum under salinity conditions in the greenhouse growing. J. Tekir. Agricul. Fac., 10, 48-58 (2013).

Akat, H. and M.E. Ozzambak: The effects of $\mathrm{Ca}$ application on some stress parameters under salinity conditions in the open field growing of Limonium sinuatum. J. Agricul. Fac. Ege Univ., 51, 5968 (2014).

Akat, H. and O. AkatSaracoglu: The effects of organic substances and foliar calcium applications on Limonium sinuatum cultivation in saline conditions. Curr. Trends Sci. Landscape Manage., 25, pp 285-295 (2017).

Al-Karaki Ghazi, N.: Growth of mycorrhizal tomato and mineral acquisition under salt stress. Mycorrhiza, 10, 51-54 (2000).

Asrar, A.W.A. and K.M. Elhindi: Alleviation of drought stress of marigold (Tagetes erecta) plants by using arbuscular mycorrhizal fungi. Saudi J. Biol. Sci., 18, 93-98 (2011).

Awasthi, P., H. Karki, Vibhuti, K. Bargali and S.S. Bargali: Germination and seedling growth of pulse crop (Vigna spp.) as affected by soil salt stress. Curr. Agric. Res. J., 4, 159-170 (2016).

Bessemer, A.L. and R.T. Koide: Effect of mycorrhizal colonization and P on ethylene production by snapdragon (Antirrhinum majus L.) flowers. Mycorrhiza, 9, 161-166 (1999).

Black, C.A.: Methods of Soil Analysis Part-2. USA, pp. 1372-1376 (1965).

Bremner, J.M.: Inorganic forms of nitrogen. American Soc. Argon. Inc. Publ. Madison Wis. USA, pp. 1197-1287 (1965).

Brohi, A.A., A. Aydeniz, M.R. Karaman and S. Erşahin: Plant Nutrition. Gazi Osman Paşa University, Faculty of Agriculture Publishing: 4, Books Series:4 Tokat, Turkey, p. 230 (1994).

Carter, C.T. and C.M. Grieve: Salt tolerance of floriculture crops. In: Ecophysiology of high salinity tolerant plants (Eds.: E.M. Ajmal Khan and DJ. Weber). Springer Science and Business Media, pp. 279-287 (2006).

Cekic, C. and E. Yilmaz: Effect of arbuscular mycorrhiza and different doses of phosphorus on vegetative and generative components of strawberries applied with different phosphor doses in soilless culture. African J. Agric. Res., 6, 4736-4739 (2011).

Deljou, M.J.N., A. Marouf and H.J. Hamedan: Effect of inoculation with Arbuscular Mycorrhizal Fungi (AMF) on gerbera cut flower (Gerbera jamesonii) production in soil less cultivation. Acta Hortic., 1034, 417-422 (2014).

Feng, G., F.S. Zhang, X.L. Li, C.Y. Tian and C. Tang: Improved tolerance of maize plants to salt stress by arbuscular mycorrhizal is related to higher accumulation of soluble sugars in roots. Mycorrhiza, 12, 185-190 (2002).

Geren, H., H. Okkaoglu and R. Avcıoglu: Effect of mycorrhiza treatment on the yield and some physiological characteristics of Cyprus vetch (Lathyrus ochrus) under different salt ( $\mathrm{NaCl}$ ) concentrations, Ege Üniv. Zir. Fak. Dergisi, 48, 31-37 (2011).

Grieve, C.M., J.A. Poss and C. Amrhein: Response of Matthiola incana to irrigation with saline wastewaters. Hort. Sci., 41, 119-123 (2006).

Heuer, B. and I. Rauina: Growth and development of stock (Matthiola incana) under salinity. Austral. J. Agr. Res., 55, 907-910 (2004).

Jakobsen, I., L.K. Abbott and A.D. Robson: External hyphae of vesicular 
arbuscular mycorrhizal fungi associated with Trifolium subterraneum L. 2. Hyphal transport of P-32 over defined distances. New Phytol., 120, 509-516 (1992).

Kacar, B. and A. Inal: Plant Analysis. Nobel Publications, Publication No:1241, Science. Nobel Publications Limited Company, Ankara, Turkey, p. 892 (2008).

Kacar, B.: Chemical Analysis of Plant and Soil I-II. Ankara University, Faculty of Agriculture Publishing: 453, Textbook, Ankara, Turkey, p. $161(1972)$

Kaya, C., M. Asraf, O. Sonmez, S. Aydemir, A.L. Tuna and M.A. Cullu: The influence of arbuscular mycorrhizal colonization on key growth parameters and fruit yield of pepper plants grown at high salinity. Scientia Horticult., 121, 1-6 (2009).

Koksal, N., I. Kulahlıoglu, E. Ertargın and A. Torun: Relationship between salinity stress and ion uptake of hyacinth (Hyacinthus orientalis). Turk. J. Agricul. Nat. Sci., 1, 578-583 (2014).

Kumbar, I., C.P. Patil, B.S. Kulkarni, M. Shiragur and A.M. Shirol: Efficacy of Entrophospora sp. (VA Mycorrhiza) on salt tolerance and flower yield and quality of Chrysanthemum var. Marigold [Dendranthema grandiflora Tzvelev.]. Int. J. Curr. Microbiol. App. Sci., 6, 4769-4777 (2017).

Long, L.K., Q. Yao, Y.H. Huang, R.H. Yang, J. Guo and H.H. Zhu: Effects of arbuscular mycorrhizal fungi on zinnia and the different colonization between Gigaspora and Glomus. World J. Microb. Biot., 26, 1527-1531 (2010).

McGonigle, T.P., M.H. Miller, D.G. Evas, D.L. Fairchild and G.A. Swim: A new method which gives an objective measure of colanisation of roots by vesicular-arbuscular mycorrhizal fungi. New Phytol., 115, 495-501 (1990).

Meir, D., S. Pivania, S. Salim, N. Resnick, S. Wininger, E. Shloma and H. Kaltai: Application of mycorrhizae to ornamental horticultural crops: Lisianthus (Eustoma grandiflorum) as a test case. Span J. Agric. Res., 8, 5-10 (2010).

Miao Xie, M. and Q. Sheng Wu: Mycorrhiza modulates morphology, colar and duration of flower in hyacinth. Biotechnol., 16, 116-122 (2017).

Murkute, A.A., S. Sharma and S.K. Singh: Studies on salt stress tolerance of citrus rootstock genotypes with arbuscular mycorrhizal fungi. Horticult. Sci., 33, 70-76 (2006).

Ortas, I.: Do Maize and pepper plants depend on mycorrhizae in terms of phosphorus and zinc uptake? J. Plant Nutr., 35, 1639-1656 (2012).

Püschel, D., J. Rydlova and M. Vosatka: Can mycorrhizal inoculation stimulate the growth and flowering of peat-grown ornamental plants under standard or reduced watering? Applied Soil Ecol., 80, 93-99 (2014)

Rabie, G.H. and A.M. Almadini: Role of bioinoculants in development of salt-tolerance of Vicia faba plants under salinity stress. Afri. J. Biotechnol., 4, 210-222 (2005).

Richards, L.A.: Diagnosis and improvement of saline and alkali soil. Soil Sci., 120, 800-826 (1954).

Ruiz-Lozano, J.M. and R. Azcon: Symbiotic efficiency and infectivity of an autochthonous arbuscular mycorrhizal Glomus sp. from saline soils and Glomus deserticola under salinity. Mycorrhiza, 10, 137-143 (2000).

Shahi, C., Vibhuti, K. Bargali and S.S. Bargali: Influence of seed size and salt stress on seed germination and seedling growth of wheat (Triticum aestivumL.). Indian J. Agri. Sci., 85, 1134-1137 (2015).

Shanan, N.: Alleviation of salt stress by stimulative compounds in Matthiola incana L. plants. Inter. J. Advan. Res., 9, 665-675 (2015).

Shokri, S. and B. Maadi: Effects of arbuscular mycorrhizal fungus on the mineral nutrition and yield of Trifolium alexandrinum plants under salinity stress. J. Agron, 8, 79-83 (2009).

Sieverding, E.: Vesicular-arbuscular mycorrhiza management in tropical agrosystems. Deutsche gesellsschaft fur technische zusammenarbeit (GTZ) GmbH, Federal Republic of Germany, pp. 371 (1991)

Sohn, B.K., K.Y. Kim, S.J. Chung, W.S. Kim, S.M. Park, J.G. Kang, Y.S. Rim, J.S. Cho, T.H. Kim and H.S. Lee: Effect of the different timing of AMF inoculation an plant growth and flower quality of Chrysanthemum. Scientia Horticult., 98, 173-183 (2003).

Soliman, A., N.T. Shanan, O.N. Massoud and D.M. Swelim: Improving salinity tolerance of Acacia saligna (Labill.) plant by arbuscular mycorrhizal fungi and Rhizobium inoculation. Afri. J. Biotechnol., 11, 1259-1266 (2012).

Sonmez, F., F. Çığ, M. Erman and S. Tüfenkçi: Effects of zinc, salt and mycorrhiza applications on the development and the phosphorus and zinc uptake of maize. Yüzüncü Yıl Univ. J.Arg. Sci., 23, 1-9 (2013).

Turkan, I. and T. Demiral: Salinity tolerance mechanisms of higher plants. In: Abiotic stress and plant responses (Eds.:N.A. Khan and S. Sinngh). I.K. International Publishing House Pvt. Ltd., pp. 105-123 (2008).

Vibhuti, C. Shahi, K. Bargali and S.S. Bargali: Assessment of salt stress tolerance in three varieties of rice (Oryza sativa L.). J. Progr. Agric. 6,50-56 (2015). 